\title{
Improvement of abrasive wear resistance of the high chromium cast iron ASTM A-532 through thermal treatment cucles
}

\author{
Mejoramiento de la resistencia al desgaste abrasivo de la \\ fundición al alto cromo ASTM A-532 a través de ciclos de \\ tratamiento térmico
}

\begin{abstract}
Melhoramento da resistência ao desgaste abrasivo da fundição ao alto cromo ASTM A-532 através de ciclos de tratamento térmico
\end{abstract}

Fecha de recepción: 08 de octubre de 2015

Fecha de aprobación: 21 de diciembre de 2015

Oscar Fabián Higuera-Cobos*
Florina-Diana Dumitru**
Dairo Hernán Mesa-Grajales

\section{Abstract}

High-Chromium White Cast Iron is a material highly used in mining and drilling shafts for oil extraction, due to its high wear resistance. However, because of the austenitic matrix found in the as-cast state, an adequate heat treatment cycle is necessary. This paper studies the effects of different cooling media after a destabilization treatment on the microstructure, hardening and abrasion resistance behaviors of a hypoeutectic high chromium white cast iron. The results show that although air cooling followed by immersion in $\mathrm{CO}_{2}$ can effectively reduce the retained austenite, this is not enough to transform completely the retained austenite into martensite. The low retained austenite percentages improve bulk hardness, but they decrease the abrasion resistance of the high chromium cast iron. The best combination of hardness and wear resistance was found in the samples cooled in air, due to the percentage of retained austenite and a moderate precipitation of chromium carbide.

Keywords: High chromium white cast iron, HCWCI, White cast iron, Chromium carbides, Hardness, Wear testing, Austenite, Martensite.

\footnotetext{
* Ph.D. Universidad del Atlántico (Barranquilla-Atlántico, Colombia). oscarhiguera@mail.uniatlantico.edu.co.

** Ph.D. National Institute for Research and Development in Environmental Protection (Bucharest, Rumanía).

*** Ph.D. Universidad Tecnológica de Pereira (Pereira-Risaralda, Colombia).dhmesa@utp.edu.co.
} 


\section{Resumen}

Las fundiciones blancas de hierro al alto cromo son muy usadas en la minería y en la perforación de pozos petroleros, debido a su alta resistencia al desgaste; sin embargo, debido a que en el estado de colada su microestructura es austenítica, es necesario someterlas a un adecuado ciclo de tratamiento térmico. Este trabajo estudia los efectos de los diferentes medios de enfriamiento después de un tratamiento de desestabilización de la microestructura y, por ende, el efecto del grado de endurecimiento sobre el comportamiento a la abrasión de una fundición blanca al alto cromo hipoeutéctica. Los resultados muestran que a pesar de que el enfriamiento al aire, seguido por inmersión en $\mathrm{CO}_{2}$, puede reducir eficazmente la austenita retenida, esto no es suficiente para transformarla completamente en martensita. El bajo porcentaje de austenita retenida incrementa la dureza del material, pero disminuye la resistencia a la abrasión de las fundiciones al alto cromo. La mejor combinación de dureza y resistencia al desgaste se encontró en las muestras enfriadas al aire, debido al porcentaje de austenita retenida y a una moderada precipitación de carburos de cromo.

Palabras clave: HCWCI, Fundiciones blancas de hierro, Fundición al alto cromo, Carburos de cromo, Austenita, Martensita.

\section{Resumo}

As fundições brancas de ferro ao alto cromo são muito usadas na mineração e na perfuração de poços petroleiros, devido a sua alta resistência ao desgaste; porém, devido a que no estado de lingotamento sua microestrutura é austenítica, é necessário submetê-las a um adequado ciclo de tratamento térmico. Este trabalho estuda os efeitos dos diferentes meios de resfriamento depois de um tratamento de desestabilização da microestrutura e, consequentemente, o efeito do grau de endurecimento sobre o comportamento à abrasão de uma fundição branca ao alto cromo hipoeutética. Os resultados mostraram que apesar de que o resfriamento ao ar, seguido por imersão em $\mathrm{CO}_{2}$, pode reduzir eficazmente a austenita retida, isto não é suficiente para transformá-la completamente em martensita. A baixa porcentagem de austenita retida incrementa a dureza do material, mas diminui a resistência à abrasão das fundições ao alto cromo. A melhor combinação de dureza e resistência ao desgaste encontrou-se nas amostras resfriadas ao ar, devido à porcentagem de austenita retida e a uma moderada precipitação de carbonetos de cromo.

Palavras chave: HCWCI, Fundições brancas de ferro, Fundição ao alto cromo, Carbonetos de cromo, Austenita, Martensita.

Cómo citar este artículo:

[1] O. F. Higuera-Cobos, F. D. Dumitru \& D. H. Mesa-Grajales, "Improvement of abrasive wear resistance of the high chromium cast iron ASTM A-532 through thermal treatment cycles”, Fac. Ing., vol. 25 (41), pp. 93 103, ene.-abr. 2016. 


\section{INTRODUCTION}

The High Chromium White Cast Iron (HCWCI) is a material highly used in the mining and oil industry, to manufacture crushing hammers and drilling rigs, due to the presence of a significant proportion quantity of chromium rich carbide phase in their microstructures. The high chromium white cast irons implies a good wear resistance for an extended life service [1]. The high demand of these materials led to the increment of imports in Colombia, while the local companies, that produce these materials, became a second option for the buyers. This increase in imports is caused by the better performance of the tools, as the duration of the materials is about 4-four times higher, than the tools manufactured locally. It is presumed that the behavior of this kind of Colombian materials, is caused by the large percentage of retained austenite, due to a heat treatment performed improperly [2].

According to the literature, the microstructure of the high-chromium white cast irons, influences the wear behavior. In order to obtain a better wear performance, the high chromium white cast irons should present a martensitic structure, because the martensitic formation, compared to the austenitic, minimizes cracking and removal during wear. While it was considered that the presence of residual austenite in the microstructure causes volumetric expansion which may also lead to microcracks because of the developed stresses, some investigations determined that a certain percentage of retained austenite could improve the abrasion resistance, due to its work-hardening properties [3, 4], ductility and thermodynamic metastability at room temperature [5]. According to Liu et al. [6] the best abrasion resistance is obtained when the content of retained austenite is higher than $20 \%$. An additional influence on the wear behavior is given by the secondary carbides [7], which improves the mechanical strength [8], through increasing the matrix strength.

Therefore, the microstructure must present a tough matrix and high volume fraction of hard chromium carbides $[9,10]$, such as a high carbon hard martensite matrix hardened by secondary carbides, because retained austenite reduces the hardness which might lead to a decrease in the abrasion resistance.
Along with the material composition and processing conditions the wear behavior is also influenced by heat treatment [5], which leads to a suitable microstructure [11], as the thermal activation provided by heat treatment allows precipitation of chromium carbides $[12,13]$. Heat treatment involves heating the HCWCIs up to $800-1100{ }^{\circ} \mathrm{C}$ for $1-6 \mathrm{~h}$ [14] in order to destabilize the austenite matrix by encouraging precipitation of secondary carbides, which reduces the carbon and chromium percentage in the matrix and enables the transformation to martensite in subsequent cooling from the destabilization temperature [13]. Different investigations were made on the effect of destabilization treatment parameters on the nature and morphology of secondary carbide precipitation as the distribution of secondary carbides in the martensitic matrix after heat treatment is known to improve the wear resistance [9], due to their high hardness. The hardness of $\mathrm{M}_{7} \mathrm{C}_{3}$ is in the range of $1200-1800 \mathrm{HV}$ and other carbides like $\mathrm{M}_{23} \mathrm{C}_{6}$ have hardness values between 976-1650 HV and M3C between 1060-1240 HV [15]. Following the investigation of BedollaJacuinde et al. [16], the optimum combination of martensite and finely dispersed secondary carbide precipitates which provide a proper wear resistance obtained after destabilization at $900^{\circ} \mathrm{C}$ for $1-2 \mathrm{~h}$.

Given the above problem, the aim of the present investigation is to establish the effect of different cooling media used after destabilization treatment on the wear resistance of a white cast iron. The study is performed in order to determine the most suitable microstructure along with improved mechanical properties of HCWCIs produced in Colombia, through an appropriate heat treatment that could increase the wear resistance and hardness, and thus improving the production approach to international standards, and helping the local industries to strengthen their position in the international market.

\section{EXPERIMENTAL PROCEDURE}

\section{A. Characterization}

A high chromium white cast iron manufactured by a regional company was used in this investigation. The material composition is summarized in Table I. 


\section{TABLE I}

\section{ChEMICAL COMPOSITION OF HIGH CHROMIUM CAST IRON}

\begin{tabular}{|c|c|c|c|c|c|}
\hline Element & C & Cr & Si & Mn & Mo \\
\hline wt. \% & 3.02 & 24.93 & 0.47 & 0.74 & 1.02 \\
\hline
\end{tabular}

According to the obtained values of the main alloying elements $(\mathrm{C}, \mathrm{Cr})$, it is assumed that the material meets the parameters of the standard ASTM A-532 Class III Type A.

The material was analyzed metallographically, and characterized by techniques of optical emission spectrometry, using Optical Emission Spectrometer ARL ASSURE, scanning electron microscopy, using an electron microscope JSM-5910LV, and X-ray diffraction, using the X-ray diffractometer Philips PW1700, equipped with a PW1825 generator and a graphite monochromator at an angle of $26^{\circ}$, using $\mathrm{Cu}$ radiation.

\section{B. Heat treatment}

The samples were destabilized at $950^{\circ} \mathrm{C}$ and maintained at this temperature for one hour, then subjected to cooling in different media (air, water, oil [Shell Voluta $\mathrm{C}]$ and air, followed by immersion in compressed $\mathrm{CO}_{2}$ or dry ice). The last treatment was applied in order to observe the effects of supercooling on the wear behavior, and it implied a 24-hour immersion of the specimens in dry ice-compressed $\mathrm{CO}_{2}$, a temperature of $-80^{\circ} \mathrm{C}$. Fig. 1 summarizes the thermal cycles used in this investigation.

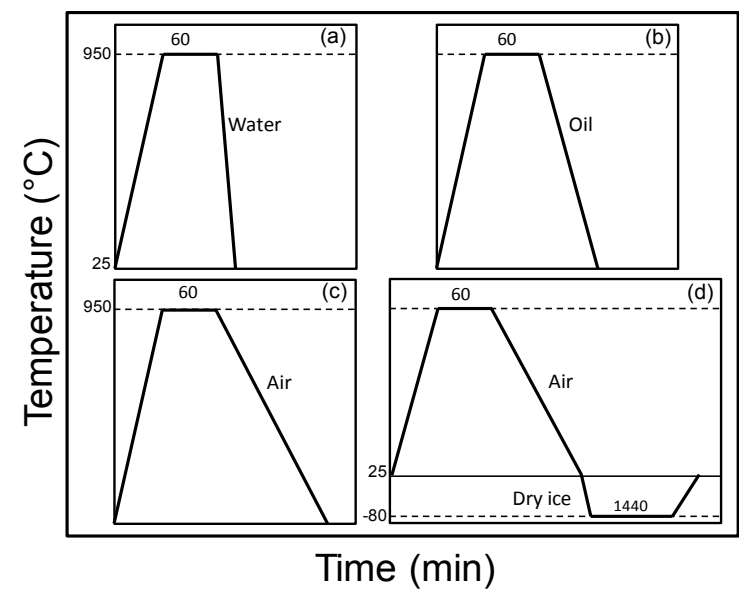

Fig. 1. Heat treatment cycles with different quenching media: a) water, b) oil, c) air and d) air and dry ice.

\section{Evaluation of mechanical properties}

The mechanical characteristics analyzed in this investigation were wear resistance and hardness.

The technique used to evaluate the resistance to abrasive wear was the rubber wheel / dry sand (see Fig. 2).

The specimens were built following the ASTM G 6500 standard and its dimensions were $7.62 \mathrm{~cm}$ long, $2.54 \mathrm{~cm}$ wide and $0.76 \mathrm{~cm}$ thick [17]. To ensure the repeatability of the test and to reduce the error in their results, five samples were used.

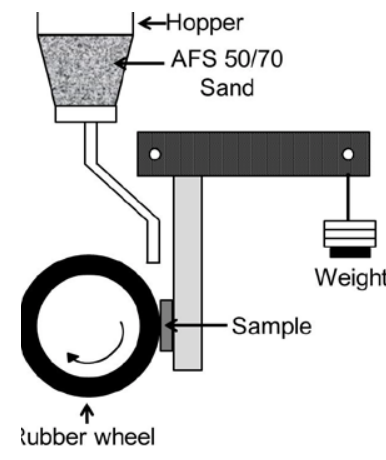

(a)

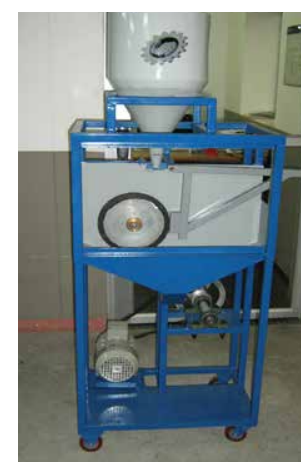

(b)
Fig. 2. (a) Schematic illustration for an abrasion system according to ASTM G-65 and (b) the abrasive wear test machine used in this study.

The volumetric loss of material was calculated using equation (1) [18]:

The hardness values for each sample were determined in order to compare the performance of the specimens after being heat treated and to calculate the wear coefficient. Hardness tests of the analyzed samples were performed on a Brinell hardness tester. A total of ten indentations were made on each sample and averaged to determine the hardness of each sample. After the hardness values were obtained, the wear coefficient (Ks) was calculated according to equation (2) $[18]:$

where: $\mathrm{V}$ is the volume of the lost material $\left(\mathrm{mm}^{3}\right)$, $\mathrm{H}$ represents the material hardness (Brinell), $\mathrm{P}$ is the 
load used in the tests $(\mathrm{kg})$ and $\mathrm{L}$ is the sliding distance (mm).

\section{RESULTS AND DISCUSSION}

\section{A. Characterization}

In order to identify the theoretical structure of the investigated alloy, the binary diagrams for $\mathrm{Fe}-\mathrm{C}$ and $\mathrm{Fe}-\mathrm{Cr}$ were analyzed. The chemical composition of the studied high chromium white cast iron was marked with 1 in Fig. 3, where according to Li et al. [2], the equilibrium phases calculated by the ThermoCalc software presented the effect of chromium content on the eutectic point, moving from $4.3 \% \mathrm{C}$ to $3.2 \% \mathrm{C}$ for the ASTM A 532 Class III Type A cast irons (Fig. 3a). During solidification of the hypoeutectic alloys, proeutectic austenite forms first followed by the monovariant eutectic reaction $\mathrm{L} \rightarrow \gamma+\mathrm{M}_{7} \mathrm{C}_{3}$. Although the cementite is practically removed due to the high proportion of chromium found in the used HCWCI, some traces of cementite may be present. Additionally, there is a decrease in the eutectic temperature, from $1280{ }^{\circ} \mathrm{C}$ to $1147^{\circ} \mathrm{C}$, which favors the presence of a higher proportion of stable chromium carbides [19].
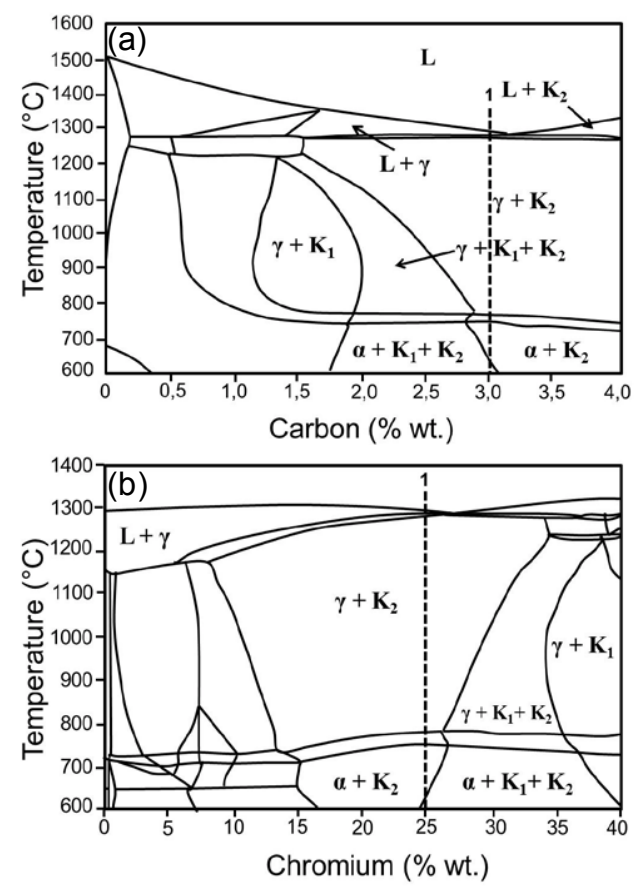

Fig. 3. Equilibrium phases calculated by ThermoCalc software [2]: (a) Fe-C system with $25 \% \mathrm{Cr}$ and (b) FeCr system with $3 \% \mathrm{C}$.
Both the as-casting and the heat treated materials were structurally characterized in order to correlate the microstructural changes with the wear behavior. The microstuctural behavior of the as-received cast iron is given in Figure 4a. It was determined that the matrix structure is predominantly austenite (austenite dendrites (proeutectic), with an approximate 1.4$1.5 \% \mathrm{C}$ and secondary austenite (eutectic)), while the precipitated chromium carbides are found along the dendrite boundaries. According to Bedolla-Jacuinde et al. [20], $\mathrm{M}_{7} \mathrm{C}_{3}$ eutectic carbides in HCWCIs nucleate on the surface of the primary and secondary dendrites arms, while the eutectic $\boldsymbol{\gamma}$-phase nucleates side-by-side with the $\mathrm{M}_{7} \mathrm{C}_{3}$ carbides. Additionally, in the center of the dendrite arms fine eutectic carbides were found, as their nucleation time from austenite was insufficient. Therefore, the as-cast microstructure is made of dendrites, which remain fully austenitic at room temperature, while the eutectic micro-constituent is a continuous network of chromium-rich carbides and eutectic austenite, similar to the investigation realized by Hann et al. [3].

A particular feature of the analyzed high chromium white cast iron was the presence of small amounts of $\mathrm{M}_{23} \mathrm{C}_{6}$ carbides, which represent the $(\mathrm{Fe}, \mathrm{Cr})_{23} \mathrm{C}_{6}$ type carbides [2], besides the $\mathrm{M}_{7} \mathrm{C}_{3}$ carbides. This behavior was encountered in other investigations [21] and could be explained by the slow solidification of the alloy. The XRD analysis was performed at Bragg angles $(2 \theta)$ between $30^{\circ}$ and $100^{\circ}$, as can be seen in Figure $4 \mathrm{~b}$. For the as-cast sample, various austenitic peaks were identified, at values of $2 \theta=42.57^{\circ}(\gamma(111)), 43.29^{\circ}$ for $\gamma$ (111) eutectic, and also the (200), (220), (311), and (222) planes were noticed, which occur at $2 \theta$ values of $50.21^{\circ}, 74.11^{\circ}, 89.67^{\circ}$ and $95.23^{\circ}$, respectively. In the case of the $\alpha$ phase, the most representative peak appears at $2 \theta=44.29^{\circ}$, corresponding to the diffraction plane (110). However, the presence of diffraction peaks of lesser intensity was noted for the (220) and (221) planes, which occur at $2 \theta$ values of $64.27^{\circ}$ and $79.25^{\circ}$, respectively. It should be noted that in the analyzed materials, the $\alpha$ phase is mainly associated to the ferrite phase. 


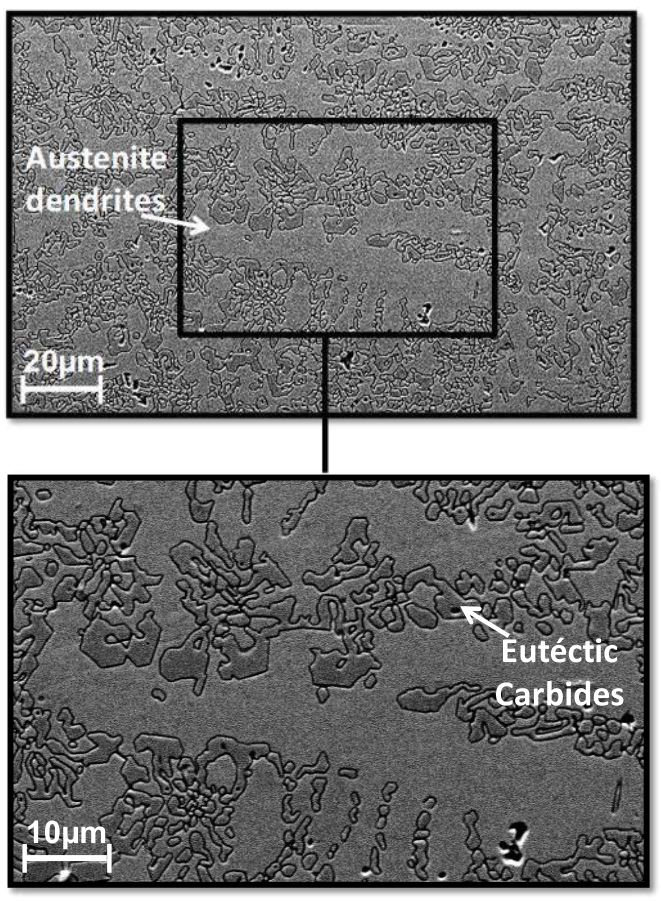

(a)

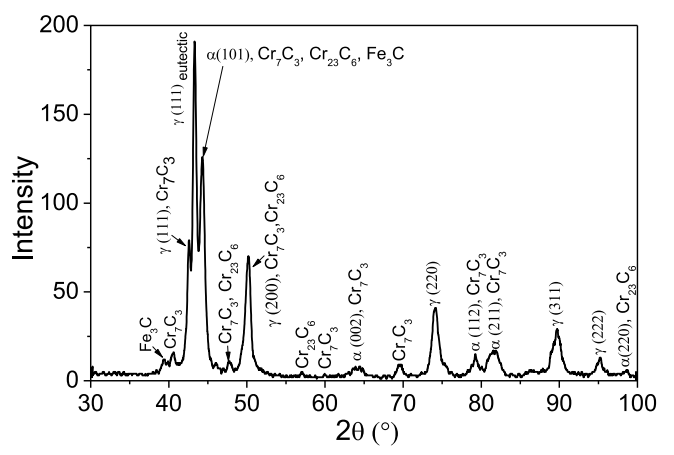

(b)

FIG. 4. (a) Scanning electron microscopy and (b) XRD of the as-received high chromium cast iron.
The XRD analysis also confirmed the presence of both $\mathrm{K}_{1}$ and $\mathrm{K}_{2}$ carbides in the structure of the as-cast samples. Through quantitative analysis of the XRD, following the ASTM standard [22], resulted a $44.5 \%$ content of austenite and a $17.3 \%$ of ferrite, at room temperature. The resulting carbide percentage was around $39.2 \%$.

Using the diagrams in Fig. 3, the as-cast was subjected to a destabilizing heat treatment at a temperature of 950 ${ }^{\circ} \mathrm{C}$, as at that temperature the matrix is supersaturated with carbon and chromium. According to Zhang et al. [23], the lower the destabilization temperature, the more carbide is precipitated and the more martensite will form. As the diagram shows the presence of the $\gamma$ phase and the characteristic $\mathrm{K}_{2}$ carbide, the distribution of these phases was determined at $950{ }^{\circ} \mathrm{C}$, for the ascast material, and the results showed approximately $66.67 \%$ austenite and $33.33 \% \mathrm{~K}_{2}$ carbide.

The microstructures of the thermally treated material are presented in Fig. 5. During the heat treatment, the ferrous matrix is supersaturated with carbon and chromium leading to the precipitation of secondary carbides. Upon cooling, the austenite matrix becomes martensite because of the secondary carbide precipitation. Therefore, after of the destabilization and cooling, the microstructures contained precipitated secondary carbides within a martensite $\left(\alpha^{\prime}\right)$ matrix and a percentage of retained austenite, together with eutectic $\mathrm{M}_{7} \mathrm{C}_{3}$ carbide and $\mathrm{M}_{23} \mathrm{C}_{6}$ in the outer regions. The degree of martensitic transformation is determined by the amount of precipitated carbides and it depends on the austenite composition [24], which in this case corresponds to $\sim 2.5 \% \mathrm{C}$ at $950{ }^{\circ} \mathrm{C}$ but increases to approximately $2.8 \% \mathrm{C}$ at $780{ }^{\circ} \mathrm{C}$. 

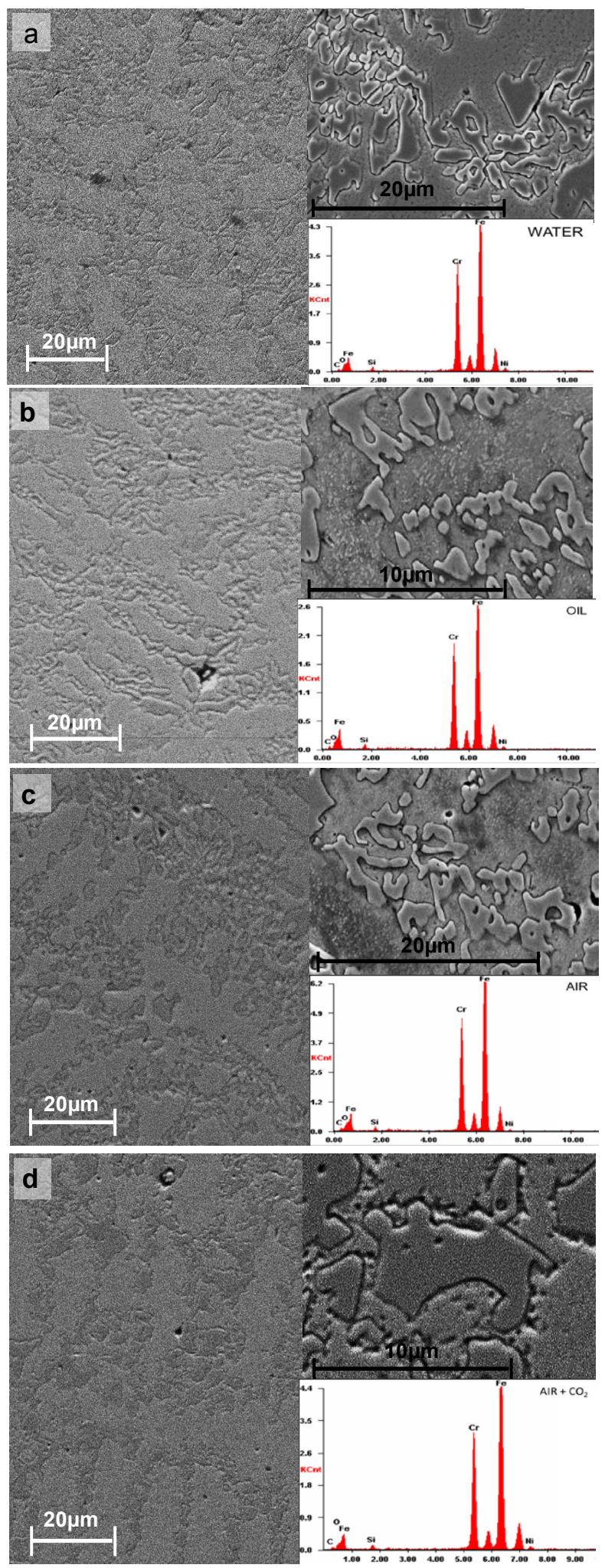

Fig. 5. SEM microstructures of samples quenched in a) water, b) oil, c) air and d) air and dry ice.
It can also be observed that the secondary chromium carbides $\left(\mathrm{M}_{7} \mathrm{C}_{3}\right.$ and $\left.\mathrm{M}_{23} \mathrm{C}_{6}\right)$ nucleated and grew within the dendritic matrix. Additionally, the secondary carbides developed a typical laminar form because of the phase changes for both the matrix and the secondary carbides, due to the thermal change that occurs. Thus, when the undercooling is smaller (because of the heat released by the formation of the $\mathrm{M}_{7} \mathrm{C}_{3}$ carbides), this type of carbide shape is favored [5].

These results are similar to those found by Hinckley et al. [25], while investigating the influence of heat treatment on high chromium cast-irons. Also, the secondary carbides are distributed more homogeneously in the treated microstructures than in the as-cast one, this behavior was also found by Wang et al. [26].

It can be observed that the samples subjected to destabilization and cooled in air present a more homogeneous distribution of finer carbides in the structure, compared with the other samples. Similar to the as-received sample, it can be seen in Fig. 6a a greater proportion of austenite at $74^{\circ}, 89^{\circ}$ and $95^{\circ}$ in the quenched samples, which are not present in the other samples due to its transformation into martensite during the heat treatment. The XRDs additionally present second-class compounds such as $(\mathrm{Fe}, \mathrm{Cr})_{7} \mathrm{C}_{3}$ and $(\mathrm{Fe}, \mathrm{Cr})_{23} \mathrm{C}_{6}$. In order to investigate the process of transformation of austenite the XRD analysis was

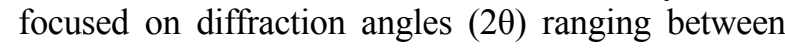
$38-52^{\circ}$ (Fig. 6b). This transformation process is critical for the wear behavior of high chromium cast irons because it is believed that the austenite generates the spalling process, the main cause of damage to this material under working conditions [27]. 

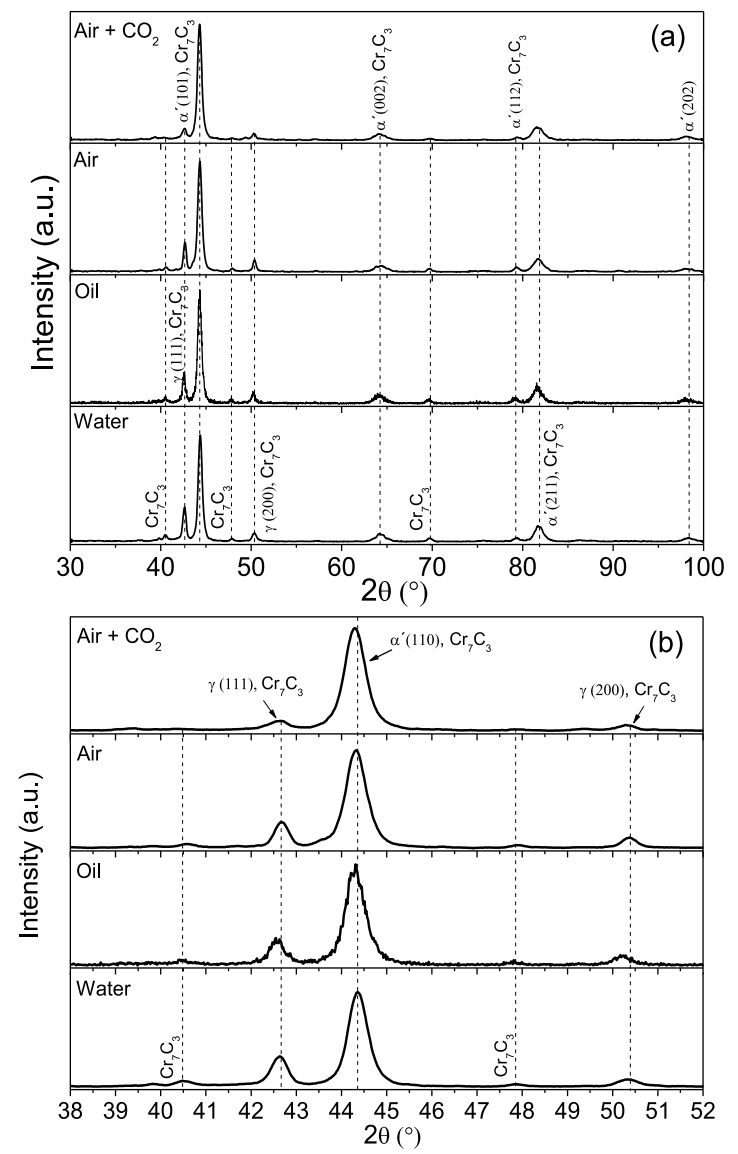

Fig. 6. XRD of the high chromium iron cast subjected to different heat treatments.

Fig. $6 \mathrm{~b}$ confirms the partial martensitic transformation after heat treatment, with the presence of the $\alpha^{\prime}(110)$ peak, but also with $\gamma(111)$ and $\gamma(200)$ austenite peaks. The intensity of the austenite peaks varies according to the media of quenching. Therefore, it can be seen that quenching in water and oil present a similar behavior with a higher $\gamma(111)$ austenite peak and a smaller intensity $\gamma(200)$ austenite peak. However, the diffraction when quenching in oil is run to the left and presents interferences. When quenching in air the $\gamma$ (111) peak is lower than those of the other two analyzed media, while the $\alpha^{\prime}(110)$ and $\gamma(200)$ peaks are higher. After an immersion in $\mathrm{CO}_{2}$ the samples present the highest intensity of the $\alpha^{\prime}(110)$ peak and lowest intensities for the austenite peaks, showing that at $-80{ }^{\circ} \mathrm{C}$ the process has not reached yet the temperature martensite finish temperature.

By means of XRD analysis, the retained austenite percentage was determined in the heat treated samples.
It was observed that the destabilization treatment reduced the retained austenite content by a factor of 2-3 from the percentage found in the as-cast samples.

The highest values of retained austenite, determined using the ASTM method [22], were encountered for samples cooled in oil $(\sim 35.5 \%)$, followed by samples cooled in water $(\sim 28.5 \%)$ and in air $(\sim 26.2 \%)$. The lowest values, around $14.3 \%$, were obtained for the samples cooled in air and subsequently immersed in $\mathrm{CO}_{2}$. Therefore, it was determined that the later cooling media can effectively reduce the proportion of austenite, which leads to the increment of fresh martensite content in the material, compared with the other cooling conditions, and it can also increase the fine secondary carbides precipitates, which can cause the dispersing strengthening effect.

\section{B. Wear resistance}

After the weight loss was determined, the values of volume loss were obtained, which are the more relevant for comparisons and calculations by using the density of the material $\left(7700 \mathrm{~kg} / \mathrm{m}^{3}\right)$. A correlation between hardness and wear behavior (volumetric loss and wear coefficient) is given in Fig. 7.
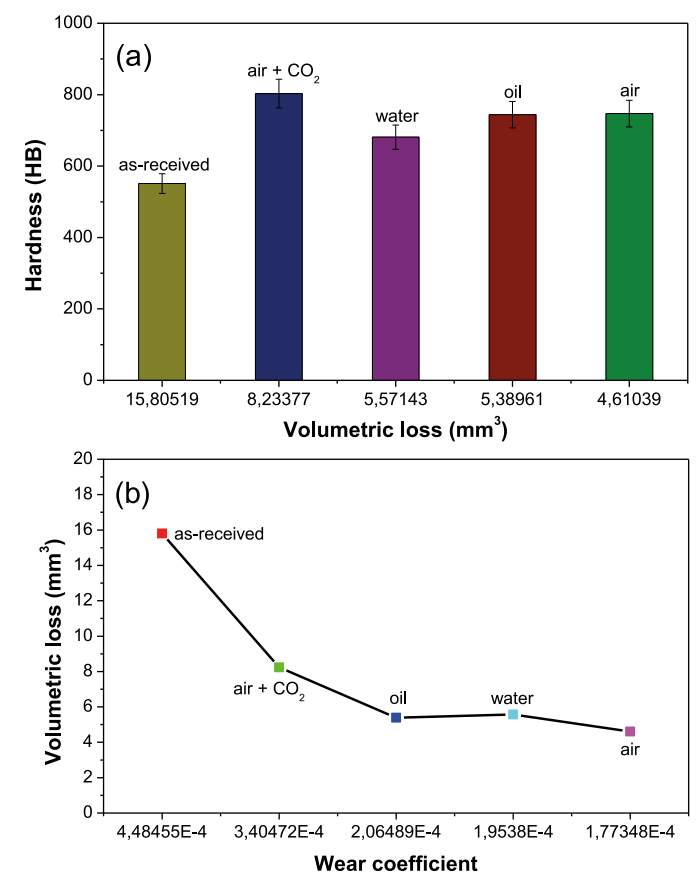

Fig. 7. Correlation between hardness and a) volumetric loss and b) wear coefficient. 
It can be seen that the as-received cast iron presents a lower hardness and higher values of volumetric loss and wear coefficient than the heat treated samples, showing the dependence of the wear behavior on the matrix microstructure. Thus, the high degree of strain hardening that occurs in the austenitic matrix, as a result of the plastic deformation caused by the normal and the tangential forces of the moving abrasive particles, leads to a lower wear resistance in the as-cast material [5]. This hardness value is lower than the one obtained by Marathray et al. [28] for a conventionally cast iron $(25.82 \mathrm{wt} . \% \mathrm{Cr}-2.95 \mathrm{wt} . \% \mathrm{C})$.

Due to the precipitation of secondary carbides within the martensite matrix, after the destabilization heat treatment, the samples present an increase in the hardness which leads to a wear resistance higher than that of the as-received material. This increased hardness could be the result of the precipitation of secondary carbides, which destabilized the austenite leading to the formation of a martensite matrix, by increasing the matrix strength through a dispersion hardening effect; the fine secondary carbides can increase the mechanical support of the eutectic carbides [24]. As the martensitic structure is recognized to provide a higher wear resistance, it was assumed that reducing the retained austenite to low percentages would lead to a better wear behavior. However, it was determined that even though a low percentage of retained austenite could improve the hardness values, it could negatively affect the wear resistance, as it can be seen for the samples subjected to destabilization followed by cooling in air and subsequently overcooled in $\mathrm{CO}_{2}$. This behavior could be due to the increase of carbides without enough matrix support [10], leading to a reduced toughness, which resulted from brittle carbides. Therefore, the carbides can be more easily removed and cracked during wear. According to Filipović et al. [24] an increase in the volume fraction of the carbide phase could reduce the wear resistance, due to intensive spalling of massive carbides during wear. Also, the direction in which the carbides are oriented influences the abrasive wear resistance, since, if the carbides are perpendicular to the surface being subjected to friction, it will be more affected than in the case where the carbides are oriented parallel to the same area [29].

Therefore, a certain minimum percentage of retained austenite is required in order to provide the best wear performance. As it can be seen from Fig. 7 the samples cooled in air show a suitable behavior after treatment, presenting favorable results in the abrasion resistance and increased hardness, because of the moderate precipitation of chromium carbide due to low cooling rate and the percentage of carbon and other alloying elements present in the material.

\section{Conclusions}

The influence of different cooling media after destabilization heat treatments on high chromium white cast iron was investigated. The microstructure of the as-cast presented an austenitic matrix (austenite dendrites (proeutectic), secondary austenite (eutectic)), with precipitated chromium carbides found along the dendrite boundaries. The XRD analysis revealed the presence of austenitic peaks, but also ferrite and carbides, with a percentage of $44.5 \%, 17.3 \%$, and $39.2 \%$, respectively.

The as-received material was subjected to a destabilization at $950{ }^{\circ} \mathrm{C}$, followed by cooling in different media. After the heat treatments, the cast iron presented a transformation of the primary austenite to martensite, while the secondary chromium carbides $\left(\mathrm{M}_{7} \mathrm{C}_{3}\right.$ and $\left.\mathrm{M}_{23} \mathrm{C}_{6}\right)$ nucleated and grew within the dendritic matrix. It was determined that the cooling media subsequent to the destabilization treatment can effectively reduce the proportion of austenite, to $\sim 35.5 \%$ for the samples cooled in oil, $\sim 28.5 \%$ for the samples cooled in water, $\sim 26.2 \%$ for the ones cooled in air, and to a lowest of $14.3 \%$ for the samples cooled in air and subsequently immersed in $\mathrm{CO}_{2}$.

While the as-cast presented a lower hardness and consequently a lower wear resistance, after the heat treatments the samples showed an improvement of these characteristics, due to the precipitation of secondary carbides within the martensite matrix and reduction of retained austenite.

The samples cooled in air showed the best results regarding the abrasion resistance hardness because of the optimal combination between retained austenite and moderate precipitation of chromium carbide.

\section{REFERENCES}

[1] I. R. Sare, "Abrasion resistance and fracture toughness of white cast irons", Met. Technol. 
6, pp. 412-419, 1979. DOI: http://dx.doi. org/10.1179/030716979803276228.

[2] D. Li, et al., "Phase diagram calculation of high chromium cast irons and influence of its chemical composition", Materials \& Design 30, pp. 340-345, 2009. DOI: http://dx.doi. org/10.1016/j.matdes.2008.04.061.

[3] S. K. Hann and J. D. Gates, "A transformation toughening white cast iron", Journal of Materials Science 32, pp.1249-1259, 1997. DOI: http:// dx.doi.org/10.1023/A:1018544204267.

[4] H. Liu, et al., "Effects of cryogenic treatment on microstructure and abrasion resistance of $\mathrm{CrMnB}$ high chromium cast iron subjected to sub-critical treatment", Mater. Sci. Eng. A, pp. 478, 324-328, 2008. DOI: http://dx.doi. org/10.1016/j.msea.2007.06.012.

[5] Ö. N. Doğan, J. A. Hawk and G. L. laird II, "Solidification structure and abrasion resistance of high chromium white irons", Metallurgical and Materials Transactions A 28A, pp.13151328,1997. DOI: http://dx.doi.org/10.1007/ s11661-997-0267-3.

[6] H. Liu, et al., "Effects of deep cryogenic treatment on property of $3 \mathrm{Cr} 13 \mathrm{Mo1V} 1.5$ high chromium cast iron", Materials \& Design 28, pp.1059-1064, 2007. DOI: http://dx.doi. org/10.1016/j.matdes.2005.09.007.

[7] A. Kootsookos and J. D. Gates, "The role of secondary carbide precipitation on the fracture toughness of a reduced carbon white iron", Mater. Sci. Eng. A 490, pp. 313-318, 2008. DOI: http://dx.doi.org/10.1016/j.msea.2008.01.036.

[8] Ș. Yașar, Investigation of wear and microstructure of turbine pallet of sanding machine, Institute of Science and Technology, Gazi University, Ankara, Turkey, 2001.

[9] C. Çetinkaya, "An investigation of the wear behaviours of white cast irons under different compositions", Materials and Design 27, pp. 437-445, 2006. DOI: http://dx.doi.org/10.1016/j. matdes.2004.11.021.

[10] X. H. Tang, et al., "Microstructure of high (45 wt.\%) chromium cast irons and their resistances to wear and corrosion", Wear 271, pp.1426-1431, 2011. DOI: http://dx.doi. org/10.1016/j.wear.2010.11.047.

[11] X. Zhi, et al., "Effect of heat treatment on microstructure and mechanical properties of a Ti-bearing hypereutectic high chromium white cast iron", Mater. Sci. Eng. A 487, pp.171179, 2008. DOI: http://dx.doi.org/10.1016/j. msea.2007.10.009.

[12] I. R. Sare, B. K. Arnold, "The Effect of Heat Treatment on the Gouging Abrasion Resistance of Alloy White Cast Irons", Metallurgical and Materials Transactions A 26A, pp.357-370, 1995.

[13] A. Wiengmoon, et al., "Microstructural and crystallographical study of carbides in $30 \mathrm{wt} . \% \mathrm{Cr}$ cast irons", Acta Materialia 53, pp.41434154, 2005. DOI: http://dx.doi.org/10.1016/j. actamat.2005.05.019.

[14] A. E. Karantzalis, A. Lekatou, E. Diavati, "Effect of destabilization heat treatments on the microstructure of high-chromium cast iron: a microscopy examination approach", Journal of Materials Engineering and Performance 18, pp.1078-1085, 2009. DOI: http://dx.doi. org/10.1007/s11665-009-9353-6.

[15] R. J. Chung, et al. "Microstructure refinement of hypereutectic high $\mathrm{Cr}$ cast irons using hard carbide-forming elements for improved wear resistance", Wear 301, pp. 695-706, 2013. DOI: http://dx.doi.org/10.1016/j.wear.2013.01.079.

[16] A. Bedolla-Jacuinde, L. Arias and B. Hernández, "Kinetics of secondary carbides precipitation in a high-chromium white iron", J. Mater. Eng. Perform. 12, pp. 371-382, 2003. DOI: http:// dx.doi.org/10.1361/105994903770342881.

[17] ASTM, Standard G 65-00, Standard Test Method for Measuring Abrasion Using the Dry Sand/Rubber Wheel Apparatus, Pennsylvania, U.S.A.: ASTM International, 2001.

[18] ASM, Handbook, Friction, Lubrication, and Wear Technology. Décima edición, in: A. International (Ed.) 1992.

[19] V. Dobrovolsky, et al., Machine Elements, Moscow Peace Publisher, 1976.

[20] A. Bedolla-Jacuinde, B. Hernández, and L. Béjar-Gómez, "SEM study on the M7C3 carbide nucleation during eutectic solidification of high-chromium white irons", Zeitschrift für Metallkunde. 96, pp.1380-1385, 2005. DOI: http://dx.doi.org/10.3139/146.101188.

[21] K. A. Kibble, J. T. H. Pearce, "Influence of heat treatment on the microstructure and hardness of 19\% high-chromium cast irons", Cast Metals 6, pp. 9-15, 1993. 
[22] ASTM, E 975-03, Standard Practice for X-Ray Determination of Retained Austenite in Steel with Near Random Crystallographic Orientation, Pennsylvania, U.S.A.: ASTM International, 2003.

[23] M.-X. Zhang, et al., "Determination of retained austenite using an X-ray texture goniometer", Materials Characterization 45, pp. 39-49, 2000. DOI: http://dx.doi.org/10.1016/S10445803(00)00044-9.

[24] M. Filipović, Ž. Kamberović, M. Korać, "The effect vanadium content and heat treatment on wear resistance and fracture toughness of Fe-Cr-C-V alloy", Metall. Mater. Eng. 20, pp. 1-13, 2014. DOI: http://dx.doi.org/10.5937/ metmateng $1401001 \mathrm{~F}$.

[25] B. Hinckley, et al., "Investigation of the Martensitic Transformation in HighChromium Cast Irons using Microscopy and Microanalysis", Materials Forum 32, pp.
55-71, 2010. DOI: http://dx.doi.org/10.1017/ s1431927610058423.

[26] J. Wang, et al., "Effects of high temperature and cryogenic treatment on the microstructure and abrasion resistance of a high chromium cast iron", Journal of Materials Processing Technology 209, pp. 3236-3240, 2009. DOI: http://dx.doi. org/10.1016/j.jmatprotec.2008.07.035.

[27] R. Blickensderfer, J. H. Tylczek and J. Dodd, "The effect of heat treatment on spalling of CrMo white cast iron", Wear of Materials, pp.471476, 1983.

[28] F. Marathray, R. Usseglio-Nanot, Atlas: Transformation Characteristics of Chromium and Chromium-Molybdenum White Irons, Paris: C. M. S.A. (Ed.), pp. 149-152, 1970.

[29] Ö. N. Doğan, J. A. Hawk, "Effect of carbide orientation on abrasion of high $\mathrm{Cr}$ white cast iron”, Wear 189, pp. 136-142, 1995. DOI: $\quad$ http://dx.doi.org/10.1016/00431648(95)06682-9. 